\title{
El contexto histórico para la reflexión teórica sobre el fenómeno de la paradiplomacia en el mundo globalizado
}

DAVID J. SARQUÍS*

Artículo recibido: $1^{\circ}$ de octubre de 2014

Artículo aprobado: 20 de febrero de 2015

Doi: dx.doi.org/10.12804/desafios28.1.2016.01

Para citar este artículo: Sarquis J., D. (2016).El contexto histórico para la reflexión teórica sobre el fenómeno de la paradiplomacia en el mundo globalizado. Desafíos, 28(I), 35-78. Doi: dx.doi.org/10.12804/desafios28.1.2016.01

'La aparición de fenómenos globales pone en duda la propia subsistencia del Estado tal como existe hoy, (...) lentamente al principio y luego a mayor velocidad, se difunde la constatación de que los Estados nacionales no están en condiciones ni de abordar los problemas globales ni de reducir los riesgos que ellos entrañan (ya que son entidades)

que resultan ineficaces ante fenómenos desterritorializados como la economía de mercados internacionales, el narcotráfico, las comunicaciones globales, las amenazas ecológicas o la distribución de la riqueza a nivel mundial". José Joaquín Brunner

\footnotetext{
* Doctor en Ciencia Política de la Universidad Nacional Autónoma de México (UNAM). Magíster en Relaciones Internacionales de La Sorbona (Francia) y magíster en Ciencia Política de la Universidad Nacional Autónoma de México (UNAM). Licenciado en Comunicación de la Universidad de Argel (Argelia). Miembro del Sistema Nacional de Investigadores (SNI-Conacyt) de México, nivel 2. Docente investigador de Tecnológico de Monterrey en el campus Estado de México. Correo electrónico: david.sarquis@itesm.mx
} 


\title{
Resumen
}

El fenómeno de la paradiplomacia es uno de los resultados más llamativos de un proceso bistórico de debilitamiento progresivo de la figura del estado-nación como actor privilegiado de los escenarios internacionales. El trabajo explora las condiciones históricas que bicieron posible, primero el surgimiento del sistema internacional contemporáneo como un conglomerado de estados soberanos, a partir de mediados del siglo XVII, su expansión progresiva a escala planetaria, con sus respectivas consecuencias y su transformación en un sistema globalizado de estados interdependientes a principios del siglo XXI. Por otra parte, intenta explicar las causas históricas de ese misterioso debilitamiento de las estructuras formales del estado soberano, mismas que han permitido el florecimiento del fenómeno de la paradiplomacia en nuestros días. Palabras clave: Paradiplomacia, estado-nación, soberanía, sistema internacional, interdependencia.

\section{The Historical Context for Theoretical Reflection Regarding Paradiplomacy in the Context of the Globalized World}

\begin{abstract}
Paradiplomacy has become one of the most intriguing results of a bistorical process of gradual weakening of the nation-state as a privileged actor of the international arena. This article explores the historical conditions that made possible, first, the emergence of the contemporary international system as a conglomerate of sovereign states, beginning in the mid-17th century, its progressive expansion at a planetary scale with its respective consequences and its transformation into a globalized system of interdependent states by the early part of the $21^{\text {st }}$ century. On the other hand, the article attempts to explain the historical causes of the mysterious weakening of the formal structures of the sovereign state, which in turn allowed the phenomenon of paradiplomacy to emerge in the contemporary world.
\end{abstract}

Keywords: Paradiplomacy, nation state, sovereignty, international system, interdependence. 


\title{
O contexto histórico para a reflexão teórica sobre o fenômeno da paradiplomacia no mundo globalizado
}

\begin{abstract}
Resumo
O fenómeno da paradiplomacia é um dos resultados mais chamativos de umprocesso bistórico de fraqueza progressiva da figura do estado-nação como ator privilegiado dos cenários internacionais. O trabalho explora as condições históricas que fizeram possivel, primeiro o surgimento do sistema internacional contemporâneo como um conglomerado de estados soberanos, a partir do meio do século XVII, sua expansão progressiva a escala planetária, com as suas respetivas consequências e a sua transformação em um sistema globalizado de estados interdependentes a princípios do século XXI. Por outra parte, tenta explicar as causas históricas dessa misteriosa fraqueza das estruturas formais do estado soberano, as mesmas que tem permitido o florescimento do fenômeno da paradiplomacia em nossos dias.

Palavras-chave: Paradiplomacia, estado-nação, soberania, sistema internacional, interdependência.
\end{abstract}

\section{Introducción}

Desde hace ya poco más de tres décadas, el tema de la paradiplomacia está presente en la agenda internacional contemporánea y viene cobrando creciente importancia, tal como atestigua la abundante literatura que éste ha generado. ${ }^{1}$ Como el propio nombre sugiere, el tema está inexorablemente vinculado a la idea original de diplomacia y, por ende, a la de política exterior como prerrogativas del Estado, aunque, obviamente, el hecho mismo de abordar un nuevo concepto sugiere la existencia de diferencias de fondo, incluso con términos similares, las cuales deben ser exploradas en detalle para dar sentido propio y facilitar el entendimiento de este complejo e interesante fenómeno que caracteriza al escenario internacional de nuestros días.

\footnotetext{
1 Hay un buen número de referencias al trabajo sobre paradiplomacia en la obra colectiva coordinada por Zeraoui (2013).
} 
La conexión semántica y estructural con los conceptos de diplomacia y política exterior nos obliga a tener que iniciar la reflexión sobre paradiplomacia recordando el alcance y significado de esos dos términos, para de ahí trascender hacia el terreno que corresponde a la paradiplomacia. No obstante, es necesario recalcar que más que un esfuerzo de caracterización de la paradiplomacia como nuevo fenómeno internacional, la intención de este trabajo es contextualizar en términos históricos las condiciones que distinguen, primero, a la política exterior y la diplomacia como práctica propia de los actores primarios del sistema internacional moderno, y luego, la transformación estructural que se genera a partir de la segunda guerra mundial, la cual desemboca en un debilitamiento del estado como actor central del escenario internacional y permite la aparición y consolidación del fenómeno de la paradiplomacia.

Tradicionalmente, la política exterior de los estados ha estado en el centro de atención de las relaciones internacionales. ${ }^{2}$ Su necesaria vinculación con la diplomacia, entendida como mecanismo de implementación de la política exterior, obliga a un estudio en paralelo, bajo el mismo rubro de ambas actividades.

La implementación (a través de la diplomacia) y la valoración de la política exterior es hoy día una de las actividades que mayor fuerza de atracción ejerce entre los internacionalistas. Dicho proceso exige de una cuidadosa revisión de la teoría del Estado, el papel que juega el derecho en el esquema de interrelación entre estados e incluso, la experiencia histórica acumulada por los distintos estados del escenario internacional en este resbaladizo terreno.

El análisis de la política exterior, además, vincula a los especialistas con los temas sustanciales de la agenda internacional, toda vez que dicha política representa, en gran medida y en primera instancia, la

\footnotetext{
2 Es un hecho ampliamente reconocido que los primeros programas académicos en relaciones internacionales tenían como objetivo central la capacitación de personal para atender las necesidades concretas del Servicio Exterior de los diferentes países que los implementaban.
} 
respuesta de los gobiernos nacionales a la temática plasmada en esa agenda. No es del todo accidental, por tanto, que el acercamiento tradicional a la política exterior conduzca a considerar a las relaciones internacionales, en su perfil académico, como un mero apéndice de la ciencia política, por más que se le dé en ese contexto, el pomposo nombre de subdisciplina. ${ }^{3}$ No obstante, hace ya más de un par de décadas que la política exterior ha dejado de ser monopolio exclusivo de los actores estatales ${ }^{4}$ por razones que vale la pena explorar con mayor detenimiento y a las que volveremos más adelante, justamente porque contribuyen en gran medida a explicar los orígenes y el alcance de la idea actual de paradiplomacia.

Aunque algunos analistas estiman que este fenómeno empezó a ser perceptible prácticamente desde el término de la Segunda Guerra Mundial, la aseveración parece un tanto exagerada, aunque no del todo incorrecta, y tendría que matizarse con mucho cuidado. De hecho, como intento señalar en este trabajo, por una parte, el periodo de la Guerra Fría (1946-1991) es realmente el momento histórico de consolidación, más no de surgimiento de la idea del Estado Nacional como actor primordial del escenario internacional ${ }^{5} \mathrm{y}$, por otra, justo

3 Por cierto que aquí encontramos también, en gran medida, los orígenes del engorroso, pero inevitable debate sobre la condición disciplinaria de las relaciones internacionales. Ver, Sarquís (2014).

4 Esta observación puede resultar controvertida, sobre todo para los puristas de la ciencia política, quienes consideran que la política exterior, por definición, sólo puede ser concebida como actividad (y prerrogativa) del Estado para vincularse con otros estados. Estrictamente hablando, así debería de ser. Sin embargo, la realidad es con frecuencia reacia a ajustarse a la rigidez de los conceptos. Veleidosa y cambiante, como suele ser, genera fenómenos que están claramente relacionados entre sí de manera estructural, pero que, al mismo tiempo, manifiestan características propias, para las cuales no siempre disponemos de conceptos exclusivos (ni los podemos crear), cuestión que hace del lenguaje y la comunicación procesos sumamente complicados.

En este sentido, trataremos de probar que las condiciones cambiantes del escenario internacional del siglo XXI han generado un debilitamiento estructural del estado soberano tradicional, que ha abierto la puerta para el surgimiento de una multitud de nuevos actores internacionales a través de sus procesos de interacción con otros actores sociales. Esto además exige una reconceptualización de la idea original de política exterior.

5 Por supuesto que podemos rastrear el surgimiento de la idea hasta las postrimerías de la Edad Media en Europa Occidental, pero es durante el periodo de la Guerra Fría que la mayor parte de los actores del escenario internacional empiezan a configurarse como esta- 
en función de lo anterior y aunado a las condiciones de la disputa ideológica entre las grandes potencias y el establecimiento rígido de esferas de influencia, es también un momento en que los nacientes estados "nacionales" se atrincheran tras sus propias fronteras, obligados por las circunstancias, para así tratar de identificar y proteger sus propios intereses. Esta situación les lleva a buscar mantener un hermético control de su política exterior y de su práctica diplomática, preferentemente limitando los contactos con el exterior a través de los rígidos mecanismos de la burocracia estatal. Esto es algo que ha cambiado visiblemente en el escenario internacional de las últimas tres décadas.

En la medida en que las restricciones al contacto con el exterior se fueron aligerando hacia principios de la última década del siglo pasado, como producto del deshielo bipolar, los canales de interacción entre los estados empezaron a ampliarse, los actores mismos, a diversificarse y, en consecuencia, el escenario internacional se volvió mucho más complejo. Es en este contexto que podemos empezar a hablar con propiedad del fenómeno de la paradiplomacia y que disponemos ya de elementos fiables para caracterizarlo, lo cual no impide, desde luego, buscar antecedentes históricos de este fenómeno un poco más atrás.

Aunque la reacción en el ámbito académico ha sido un tanto reticente a quitar del centro de atención a los Estados, su política exterior tradicional y su práctica diplomática, se ha tenido que ir reconociendo esta creciente complejidad escénica para lograr un mejor entendimiento de los procesos de interacción entre actores internacionales del mundo globalizado de inicios del tercer milenio. Es justamente en este contexto que hoy hablamos de nuevos procesos transnacionales, paradiplomacia, regionalización, nuevos actores, etc., temas que se convierten en nuevos objetos de estudio para los internacionalistas, ya que cada uno de ellos posee su especificidad y dinámicas propias.

dos nacionales, a pesar del hecho notable de que muchos de ellos realmente carecen de las condiciones adecuadas para hacerlo; la mayoría, de entrada, ni siquiera están conformados por naciones propiamente dichas y carecen de experiencia para la construcción del aparato estatal correspondiente. 
De este modo, la reflexión contemporánea sobre relaciones internacionales tiene que trascender con mucha mayor claridad ese enfoque estatista tradicional que las reducía preferentemente al análisis de la política exterior de los estados (como prerrogativa exclusiva de los mismos) y su práctica diplomática, en lugar de bordar sobre el proceso de construcción de un sistema internacional y sus implicaciones.

Esto no significa, como podría argumentarse desde un punto de vista ingenuo (o malicioso), que el Estado haya desaparecido de la escena internacional con el advenimiento del deshielo bipolar o que se haya reducido a mera comparsa de nuevos actores más relevantes para el proceso de construcción del sistema internacional del mundo globalizado.

De una u otra forma, el Estado sigue y seguirá siendo en el futuro previsible un elemento indispensable para el cabal entendimiento de la dinámica internacional. La influencia de las culturas locales, sus valores y tradiciones, así como sus propios marcos normativos para control de sus poblaciones, tienen aún una influencia demasiado fuerte como para permitir la disolución de los aparatos estatales sin generar un caos mayúsculo a nivel planetario. El factor cultural, con frecuencia desdeñado por los analistas como variable distintiva en la configuración del estado-nacional, muestra ahora, sobre todo a raíz de los cambios generados por el ataque a las torres gemelas de Nueva York el 11 de septiembre de 2001, la relevancia del mantenimiento de estructuras estatales propias de las diversas formas culturales que se manifiestan por el planeta, con todo y globalización.

Sin embargo, es claro que esta dinámica se mueve hoy en día a través de mecanismos mucho más complejos y sutiles que la mera voluntad expresada mediante sus designios de política exterior y sus tradicionales prácticas diplomáticas. Tan sólo en términos de los especialistas que hoy día se requieren en los órganos de servicio exterior de los estados para atender la abultada y variada agenda internacional y de la revolución en los medios de comunicación, sería virtualmente imposible confinar el trato genérico con el extranjero a los conductos formales clásicos de los estados nacionales, a través de una política 
exterior monolítica implementada por un cuerpo diplomático fijo y de perfil monotemático.

Vamos a explorar en este trabajo cómo se fueron gestando las transformaciones estructurales que redefinieron el rol de los estados en el escenario internacional, sobre todo en el último tercio del siglo $\mathrm{XX}$, y cómo estas dieron paso a nuevas formas de interacción entre colectividades humanas, analizando en particular, el caso de la paradiplomacia, para tratar de dar cuenta de las perspectivas de reconfiguración del escenario internacional en los albores del siglo XXI. Para hacerlo, sin embargo, tendremos que hacer un periplo histórico hacia los orígenes del estado soberano que explica lo específico del sistema internacional contemporáneo. Trataré de hacerlo ligero para no agobiar a las mentalidades pragmáticas que encuentran poco placer por los recorridos históricos.

\section{Las relaciones internacionales son algo más que política exterior}

El enfoque que hace de la política exterior, como expresión de la voluntad del Estado, centro de análisis de las relaciones internacionales (y que, por tanto nos coloca como apéndice de la ciencia política) no es del todo equivocado; quizá resulte limitado en cuanto a su alcance, pero, en definitiva, no es incorrecto.

Prácticamente este enfoque nace en paralelo con el desarrollo de la ciencia política, desde las postrimerías de la Edad Media y es parte importante de la reflexión que se encarga de explicar los orígenes del Estado y sus responsabilidades como organizador de la sociedad y defensor de sus intereses frente a otras entidades estatales. En consecuencia, el análisis tradicional de la política exterior no puede llevarse a cabo sin tener buenos fundamentos de teoría del estado, de la soberanía, del interés nacional, etc., aunque ciertamente no es el único camino para abordar este delicado tema. ${ }^{6}$

\footnotetext{
6 De hecho, hace ya casi un cuarto de siglo que se viene discutiendo en detalle la cuestión de la disciplinariedad y sus alcances en las ciencias sociales. A mediados de la década de los
} 
En realidad, si tomamos en cuenta los orígenes de dicho enfoque, tiene bastante sentido: tradicionalmente, la política exterior se conceptualiza como un conjunto de estrategias y mecanismos empleados por los distintos estados - a través de sus respectivas autoridades, y en función, tanto de las presiones internas que generan sus propios grupos de presión, como de las condiciones estructurales y coyunturales del exterior- para relacionarse con sus pares, es decir con otros estados, en el escenario internacional, de donde se estaría generando la dinámica que mueve en gran medida a las relaciones internacionales como praxis característica de la vida internacional. ${ }^{7}$

Como consecuencia lógica, al pensar en una disciplina para el estudio de esa praxis se piensa en algo abocado al análisis de las estrategias que los estados diseñan e implementan por medio de la diplomacia, para así vincularse con sus similares, es decir, se habla de una política exterior que necesariamente recae bajo la responsabilidad del gobierno que representa al Estado. Según puede apreciarse, el enfoque es claramente estato-céntrico, en el sentido que hace girar todo el significado de la actividad internacional en torno a la figura central del Estado, al punto en que, aun cuando se llega a reconocer la existencia de otros actores no estatales sobre el escenario internacional, en lo general se les coloca en posición subordinada con respecto a éste.

De ese modo, el Estado, que ya era figura principal de análisis para la ciencia política, permanece en su rol estelar para las relaciones internacionales, sólo que, en relación con la proyección de la actividad estatal y sus intereses, hacia afuera, es decir, frente a otros estados, lo

noventa del siglo, la Comisión Gulbenkian presentó un polémico informe que sugería con claridad las dificultades de trabajar desde departamentos estancos separados por rígidas fronteras que obstaculizaban la comunicación para abordar problemas sociales desde una perspectiva holística (integral) que tomara en cuenta la complejidad de la realidad social como conjunto en vez de simplificarla al límite separando las áreas de análisis como si no tuvieran nada que ver unas con otras, en otras palabras, que fomentara la interdisciplinariedad. Ver, Wallerstein, I. (1995), Abrir las ciencias sociales, Siglo XXI, México.

7 Una de las definiciones más acabadas y puntuales que sirve como excelente punto de partida para iniciar la reflexión sobre el tema es la de Hernández-Vela, Salgado (2002). 
que justifica el estudio de la política exterior como actividad sustantiva en el campo disciplinario de las relaciones internacionales.

No obstante, como puede observarse, el estudio queda prácticamente condicionado por la idea de que son los intereses del Estado los que están en juego y no la construcción de una entidad supra-estatal (sociedad internacional) lo que, necesariamente, cuando se aplica, da a la idea de política exterior una dimensión, en la que los estados ya no sólo están compitiendo en defensa de sus propios intereses, sino además (y en paralelo), están desplegando esfuerzos de colaboración para la construcción de una sociedad internacional, proceso de implicaciones notablemente distintas. En este contexto podemos pensar que dada la diversidad de nuevos actores internacionales y la ampliación del horizonte y más allá del interés exclusivo del estado, resulta válido hablar de política exterior en términos que puedan incluir estas nuevas características del sistema internacional.

Este enfoque es particularmente difícil de vislumbrar desde una perspectiva realista porque para esa escuela de pensamiento, la realidad internacional nunca trasciende la existencia individual de los estados. Es decir, más allá del conglomerado estatal, realmente no hay nada y la suposición de la existencia de un sistema internacional que intenta convertirse en sociedad o comunidad internacional no es más que una hipótesis de trabajo (no probada) que sólo se sustenta en buenos deseos.

Sin embargo, como hemos dicho, ésta no es la única forma de ver las cosas. Existen diversas y bien argumentadas críticas contra las limitaciones del realismo político. Las más sólidas-sobre todo bajo el enfoque de la posmodernidad- señalan que resulta difícil justificar la concepción del Estado como un actor monolítico y homogéneamente configurado, cuyos intereses pueden ser identificados sin mayor problema (Sarquís, 2013). Gran parte de la crítica marxista del siglo XIX venía precisamente del señalamiento de que el Estado, como lo concebían los juristas, era en realidad una amalgama de diversos intereses de clases sociales antagónicas, por lo que hablar de un "interés nacional" único y homogéneo siempre resultaba falaz. 
El enfoque sistémico, por su parte, contempla no sólo a las clases sociales, sino de hecho a todo grupo organizado cuya actividad tiene incidencia en la configuración de un sistema mundo, según la expresión de Wallerstein (citado por Wallerstein, 2013). En otras palabras, nos invita a pensar en el escenario internacional no sólo como un mosaico fragmentario de estados nacionales, en el que cada actor defiende a ultranza su propio interés, o como una entidad conformada por clases antagónicas que buscan imponerse una sobre otra para la implantación de un modo de producción, sino como una especie de enjambre de diversos actores internacionales, que pueden ser estados o clases sociales, pero también empresas transnacionales, organismos no gubernamentales, grupos de presión, e incluso grupos al margen de la ley, ${ }^{8}$ cuyos procesos de interacción configuran una entidad con vida propia, más allá de la de sus partes integrantes, y que podemos reconocer como un sistema internacional, el cual constituye, por ende, un objeto de estudio propio, más allá de los intereses nacionales de cada Estado, los cuales, para hacer las cosas todavía más complicadas, mantienen toda su vigencia.

Una concepción de esta naturaleza, que reconoce la amplia variedad de actores que pueden conformar un sistema internacional, abre de inmediato la posibilidad para explorar cómo es que cada uno de ellos se vincula con los demás y, de este modo, pensar en formas alternativas de contacto con el exterior, estrategias pensadas más allá del "interés nacional" predominante, que reflejen con más claridad los intereses específicos de las distintas partes que conforman a los estados y que, además, desarrollen sus propios canales de comunicación con el exterior. La idea de paradiplomacia queda, de este modo, estructuralmente vinculada a sus antecesoras, la dupla política exterior-diplomacia, pero las trasciende porque se sale del limitado marco de la acción estatal exclusivista.

\footnotetext{
8 De conformidad con el enfoque sistémico, cada uno de estos grupos puede ser representado para su estudio como un sistema, porque todos ellos tienen características en común, sin que ello signifique que sean lo mismo. El pensamiento sistémico caracteriza a la idea genérica de sistema, como un primer paso metodológico, pero en seguida nos invita a reflexionar en lo que hace distintivo a cada sistema, es decir, su especificidad. Ver: Sarquís (2005).
} 
Por supuesto que aún queda por ver qué intensión y qué extensión 9 corresponden a la idea de la paradiplomacia para hacerla realmente significativa. Como atinadamente nos ha señalado Zeraoui (2013), la idea de la paradiplomacia tiene importantes antecedentes en el derecho internacional y proyecciones culturales y políticas que no siempre son coincidentes.

\section{Algunas precisiones conceptuales breves}

Sí partimos de la idea de que un sistema internacional es un conjunto de actores sociales interactuantes en el contexto de un escenario internacional, necesitamos empezar por precisar que entendemos por escenario al espacio geo-histórico concreto que comparten un grupo de colectividades humanas políticamente organizadas de manera independiente unas de otras (Aron, 1998), lo que genera el fenómeno de un grupo doméstico frente a la otredad (Berreby, 2006). Llamamos entonces, de manera genérica, relaciones internacionales ${ }^{10}$ a los procesos de interacción que se dan entre esos grupos humanos que fungen como actores internacionales. Un actor internacional es, a partir de esta idea, un grupo humano organizado, el cual asume tener un grado de autonomía propia para el manejo de sus recursos, asuntos e intereses frente a otros grupos, cobijados por un orden jurídico distinto (y por tanto, no vinculante para todos por igual) creando con ello la dinámica que da vida y sentido a la noción de sistema internacional.

Como ya hemos apuntado, en la visión clásica más tradicional de las relaciones internacionales el actor por excelencia en el escenario

\footnotetext{
9 Cuando se define un concepto en términos de lógica formal hay que precisar puntualmente cuál es su contenido (significado) y a qué objetos o fenómenos de la realidad se refiere; esto por tanto incluye su intensión y extensión.

10 Este enfoque no está exento a controversia. Para los puristas de la disciplina, el concepto de relaciones internacionales debería estar reservado exclusivamente a la interacción entre naciones. La realidad, no obstante, es inconmensurablemente más rica que el lenguaje y no disponemos de otros términos rigurosamente definidos para referir el fenómeno genérico de la interacción entre colectividades humanas políticamente independientes. Es por ello que empleamos el concepto en una perspectiva flexible, que nos permita comprender la naturaleza histórica de largo plazo de este fenómeno, sin olvidar la especificidad que corresponde a cada formación colectiva distinta de las naciones.
} 
internacional es el Estado, preferentemente en su versión nacional, es decir, la entidad constituida por una nación, ${ }^{11}$ la cual reclama (y defiende) a un determinado territorio como propio y se gobierna a sí mismo a través de un régimen legal que cada uno se otorgamediante el aparato burocrático administrativo que lo maneja, y que también recibe el nombre de Estado.

Para efectos de este breve trabajo, según lo señalado, no requerimos en realidad de una definición demasiado acabada y puntual de política exterior; ${ }^{12}$ basta con definirla genéricamente como el diseño estratégico de políticas públicas que los estados conciben, diseñan e implementan para relacionarse con el mundo exterior, constituido por otros estados, para ir bordando gradualmente hacia una concepción ampliada de la política exterior en el mundo globalizado, donde paulatinamente (queremos pensar) se está gestando la construcción de una sociedad internacional con activa participación de nuevos actores internacionales.

Vale la pena enfatizar que si de entrada concebimos al escenario internacional como un conglomerado de estados que interaccionan de manera estrictamente voluntarista y en defensa de sus propios intereses, como se hizo en un principio, cuando empezó a desarrollarse el pensamiento político moderno, el enfoque no sólo tiene sentido, sino que además se nos sugiere como la forma idónea de concebir la política exterior, porque de hecho, así fue como se concibió originalmente la idea de un escenario internacional y se inició la reflexión

\footnotetext{
11 La nación es una de las formas de agrupación humana más complejas y difíciles de definir. Se trata, ciertamente de un grupo de gente, pero claro, no todo grupo humano constituye una nación. El problema para identificar a un grupo como tal radica en la identificación de las variables que determina su configuración. Tradicionalmente, los grupos anteriores a la nación estaban delimitados por su origen étnico, su lenguaje, su religión, su historia y sus valores comunes. Las naciones modernas contienen, pero transcienden estas variables. En una nación moderna pueden existir miembros de origen étnico, lenguaje o religión diversos. El factor aglutinante es más bien de tipo cultural y está definido por un sentimiento subjetivo de pertenencia al grupo basado en un estilo de vida. Ver: Anderson (2006).

12 Además de la definición ya señalada en la obra de Hernández-Vela (2002), entre algunos de los textos clásicos de la materia, que acometen esa tarea cabe destacar los de Ojeda (1976) y Velázquez Flores (2007).
} 
sobre el mismo, hace poco más de tres siglos y medio. La diplomacia, en ese contexto y bajo tal influencia, ha sido concebida en gran medida como el arte de poner en práctica esa política exterior (incluso a través de artimañas para el logro de sus objetivos). La paradiplomacia empieza, a partir de aquí, a perfilarse como actividad desplegada por actores internacionales no estatales que operan sobre sus propias bases e intereses, independientemente de cómo se acomoden éstos al llamado interés "nacional".

El enfoque inicial para la caracterización del escenario internacional como un mosaico de actores independientes fue cuestionado casi desde el principio, sobre todo a través de la incipiente idea de sociedad internacional que se desarrolló por esa misma época ${ }^{13}$ predominantemente en el campo de los juristas, y esto es importante porque nos permite entender la naturaleza del pensamiento que justifica la razón de estado, pero, al mismo tiempo, nos permite reconsiderar a la luz de la coyuntura actual, la conveniencia (incluso quizá, la necesidad) de ir más allá del realismo clásico, en busca del sustento teórico para dar fundamento a la idea de la sociedad internacional del mundo globalizado.

Esto sugiere que, en efecto, hay distintas formas de representarnos un sistema internacional, pero eso depende de los supuestos epistemológicos de los cuales estemos partiendo. Para los más puristas, el concepto de sistema internacional sólo debería aplicarse, sobre todo en sus orígenes, al sistema de estados que se forma en Europa occidental, a mediados del siglo XVII, a raíz del proceso gradual de

\footnotetext{
13 De hecho, la idea de una comunidad cristiana organizada a la manera de una sociedad internacional está claramente presente en escritos medievales como el Polycraticus de John de Salisbury o ElDefensor de la Fe de Marsilio de Padua, obras que sin duda ejercieron una gran influencia en autores posteriores, como Raymundo Lulio, Dante Alighieri o Emeric Crucé, el Duque de Sully, William Penn o el Abad St. Pierre, quienes mantuvieron vigente la idea de una sociedad internacional incluso después de la ruptura de la cristiandad durante la primera mitad del siglo XVI y alentaron con ello los esfuerzos tendientes a la organización internacional. De hecho, es justamente la herencia político-cultural de esa cristiandad, la que hace posible las reflexiones de Francisco de Vittoria \& Francisco Suárez, las cuales dan lugar al surgimiento del Derecho Internacional Público Moderno, porque facilitan, para la elaboración de su razonamiento, la idea de un bien comúnsupranacional.
} 
ruptura y fragmentación del mundo de la cristiandad ${ }^{14}$ que inició más de un siglo antes.

De nueva cuenta, el enfoque tradicional no es del todo equivocado, ya que se centra en la especificidad de la experiencia histórica que da paso al surgimiento del sistema internacional contemporáneo, pero es limitado en cuanto a que deja fuera de consideración la experiencia histórica de más largo alcance, en la que podemos apreciar el proceso de surgimiento, desarrollo y transformación de sistemas internacionales históricos como un movimiento recurrente al paso del tiempo, una regularidad sociológica, como diría Aron (1967), con sus respectivas similitudes y diferencias en cada caso, lo que genera el fenómeno de la singularidad histórico-concreta. ${ }^{15}$

En principio, y trabajando desde la perspectiva purista, es el surgimiento del Estado soberano moderno, (no el estado nacional que es mucho más tardío) el que marca el nacimiento mismo del sistema internacional contemporáneo, llamado westfaliano, e invita casi en automático a representarnos la interacción interestatal como una lucha inevitable por la mera supervivencia, debido a la ausencia de un poder supremo capaz de regular la interacción entre Estados, enfoque que es ya claramente perceptible en El Leviatán de Hobbes.

De este modo, el diseño de política exterior de cada uno de ellos va a reflejar esa necesidad de supervivencia en un ambiente anárquico y hostil, (el estado de naturaleza hobbesiano) en el que el poder que logra acumular cada una de estas entidades es su mejor garantía de

14 Ese proceso empieza a hacerse palpable con la reforma luterana de 1517, cuando Lutero clava sus famosas tesis contra los excesos de la política papal católica, pero obviamente tiene raíces históricas más profundas.

15 Para una concepción más flexible de la idea de sistema internacional ver: Sarquís (2012). En este trabajo, sugiero que el sistema internacional contemporáneo no es sino uno más entre una extensa gama de ejemplos de configuración de entidades políticamente autónomas que se van estructurando conforme a un patrón de regularidad que arranca desde una fase original de anarquía, ocasionada por la falta de una autoridad central hasta una fase de relativa homogeneización bajo la égida de una potencia hegemónica, aunque obviamente, cada ejemplo histórico posee su propia especificidad. 
subsistencia, en tanto no exista un poder común que las regule a todas ellas, cosa que Hobbes (y junto con él todos los realistas contemporáneos) consideran prácticamente imposible. Un diseño de política exterior inspirado por ideales basados en la idea de la cooperación y la creación de instituciones supranacionales, como los sugeridos por Rousseau, Locke, William Penn, el abad St. Pierre o Immanuel Kant, por sólo nombrar algunos, tendría obviamente una orientación distinta.

En el ámbito interno, por otro lado, donde un contrato social (siempre según Hobbes y luego todos los contractualistas) ha conferido al monarca la representatividad del Estado, la ventaja es haber superado la condición de naturaleza en el que todos luchan contra todos, cediendo al soberano el privilegio de hacer e implementar leyes que regulen la convivencia social y las facultades para sancionar a los transgresores. En este esquema, la única forma de mantener la unidad social es manteniendo un férreo control de toda la actividad estatal, especialmente en las áreas de la política exterior y la diplomacia, lo que explica con claridad que durante tanto tiempo, política exterior y diplomacia hayan sido consideradas como actividades pertenecientes al ámbito exclusivo del monopolio estatal, sin que ello signifique la ausencia total de notables excepciones.

Es necesario no perder de vista que, incluso antes que nacional, es el Estado soberano (que originalmente fue un estado absolutista) el que da razón de ser y fundamento a la idea de un sistema internacional contemporáneo. El realismo político, como propuesta teórico metodológica, se inspira claramente en la idea de que el escenario internacional es, antes que otra cosa, un campo de batalla entre estados de pretensiones soberanas, en el que cada participante está obligado a la defensa de sus intereses más elementales; más aún, este mismo principio básico hace operativo cualquier desarrollo histórico internacional, por lo que una vez asimilado, el analista podrá observar cambios en la forma, pero sobre un sustrato que permanece invariable (el de la lucha por el poder); es precisamente en este sentido que se ha acusado al realismo clásico y a todas sus variantes de ser esencialmente ahistórico, no porque se niegue a aceptar cambios de 
condiciones en distintas épocas, sino porque rechaza que éstos afecten de manera sustancial el sustrato sobre el que se da la interacción entre actores internacionales: la incesante lucha por el poder que irremediablemente todo lo condiciona.

Pero, como ya hemos señalado, ésta no es la única forma de representarnos mentalmente un escenario internacional. Si en vez de pensar al medio internacional como un conglomerado de actores unitarios y monolíticos empeñados en la defensa a ultranza de sus propios intereses, ${ }^{16}$ nos lo representamos como un ensamble de comportamiento sistémico, ${ }^{17}$-en el que diversos subsistemas (actores internacionales) establecen lazos vinculantes que contribuyen a la definición estructural de un sistema internacional y constituye algo más que la mera suma mecánica de sus partes- no resulta tan difícil traer a la palestra la idea de distintos modos de interacción estatal, como la cooperación internacional, incluso a través de actores subestatales, supraestatales o no estatales.

Este enfoque no sólo sirve para contrarrestar el predominio de la idea sobre el papel central que juega el Estado o la idea del conflicto en las relaciones internacionales, sino de hecho, para visualizar a la historia misma de las relaciones internacionales en su conjunto (incluyendo la de los actores no-estatales) como un proceso cíclico de construcción y reconstrucción de sistemas internacionales, que originalmente parten de un ambiente de anarquía y que gradualmente (aunque no siempre con éxito) se encaminan hacia un proceso de institucionalización, generador de regímenes internacionales, los cuales dotan de sustancia a la idea misma de sociedad internacional, hasta que por diversos motivos ésta se transforma y, a veces incluso se desintegra y se desvanece para convertirse en terreno propicio para recomenzar

16 Esta representación puede hacerse a través de distintas imágenes. Una de las más comunes es la de la mesa de billar, otra es la del tablero de ajedrez, y más recientemente, desde un punto de vista geopolítico, como un archipiélago. El punto clave es, no obstante, su denominador común de entidades unitarias en pugna, lo que necesariamente nos lleva a poner el énfasis en el carácter irremediablemente conflictivo de la interacción.

17 Una forma elemental de definir el comportamiento sistémico es entenderlo como la tendencia de todo sistema de transitar del caos al orden. Ver Prigogine, Ilya, \& Stengers (1984). 
el ciclo. ${ }^{18}$ Muchos pueden ver aquí el riesgo de un planteamiento determinista; no obstante, cuando se estudia con detenimiento la naturaleza dinámica y probabilística de los sistemas complejos, se puede superar sin mayor problema ese escollo. ${ }^{19}$

Un enfoque de esta naturaleza, nos lleva claramente a la necesidad de repensar la tarea del diseño de política exterior, ya no exclusivamente como un ejercicio en defensa de la soberanía nacional, como se ha hecho durante mucho tiempo, sino como un esfuerzo de coordinación de intereses entre los actores internacionales, no sólo Estados, (idealmente en busca del bien común, como señalan los partidarios del llamado idealismo jurídico). En el contexto de un sistema internacional globalizado, este último es, sin lugar a duda, el mayor de los retos para una visión ampliada de política exterior que incluso se perfila también como actividad de actores no estatales. En este sentido, podemos hacer notar que las actividades de paradiplomacia, a diferencia de las de la diplomacia clásica se enfocan predominantemente en el esfuerzo de coordinación de intereses entre las partes más que en la defensa a ultranza el interés propio.

Muchos analistas se empeñan en demostrar el carácter mutuamente excluyente de ambas visiones: la de la jungla, que representa el mosaico de estados, y la de la sociedad en construcción, a partir de la interacción de diversos actores internacionales. Si el escenario internacional es inherentemente anárquico, dicen los realistas, entonces, las posibilidades de la cooperación internacional son siempre limitadas, en el mejor de los casos, ya que los actores unitarios sobrepondrán irremediablemente sus propios intereses ante los de los demás, cuyo carácter esencialmente soberano les conducirá, de forma inevitable, en la misma dirección. En este caso, la política exterior no puede ser

\footnotetext{
18 La teoría de los regímenes internacionales tiene diversos exponentes, aparte del trabajo clásico de Krasner, Krasner (1983), se pueden consultar algunas otras obras como: Axelrod (1984); Hasenclever \& Rittberger (1997), y Oye (1986). En todas ellas se discute la posibilidad de la cooperación como alternativa ante el conflicto y se sugiere la idea de una gradual institucionalización de los escenarios internacionales como parte del proceso civilizatorio de la humanidad.
}

19 El trabajo de Briggs \& Peat (1991) es especialmente ilustrativo al respecto. 
más que estatal y no puede hacer otra cosa que velar por los intereses del estado que la genera (de donde la necesidad de mantenerla como tarea exclusiva de la autoridad estatal), como aparentemente tiende a demostrar la historia (en la visión realista).

En estas circunstancias, la anarquía parece ser un fruto natural de la idea de soberanía (que no reconoce a ningún poder por encima de sí misma) y, si el sistema internacional contemporáneo se forma a partir de la existencia de estados soberanos, entonces prosigue la lógica realista, y será irremediablemente anárquico por los siglos de los siglos, ya que cada estado, para lograr subsistir tendrá que aferrarse al privilegio de diseñar su propia política exterior e implementarla a través de su práctica diplomática.

Pero, ¿es en verdad irremediablemente anárquico un sistema internacional? La práctica internacional de la historia moderna y contemporánea permite cuestionar con bases firmes tal enfoque. Cuestionar, por supuesto, no es lo mismo que negar. Difícilmente se podría negar el carácter competitivo y con frecuencia fratricida del comportamiento interestatal (especialmente en el caso del sistema internacional contemporáneo) o las dificultades propias de cualquier intento de institucionalización en el plano internacional. No obstante, como claramente sugiere Rifkin (2010), la supervivencia misma de la especie habría sido notablemente más difícil en ausencia de un decidido espíritu de cooperación que de hecho ha permitido nuestro desarrollo civilizador. La paradiplomacia contemporánea parece inclinada a profundizar la búsqueda en la dirección de la colaboración y la tolerancia, (sin dejar de pensar en intereses individuales, enfocándose con un poco más de claridad en la idea de un bien común.

Desde esta perspectiva, incluso un análisis somero de la historia reciente de las relaciones internacionales muestra fehacientemente los avances de la tendencia hacia una progresiva organización del sistema, mediante la creación de marcos jurídicos institucionalizantes (no necesariamente de forma óptima o definitiva) sobre todo motivada por la magnitud de los retos que enfrentamos hoy en día, no sólo en los ámbitos locales y regionales, sino también en el plano internacional, 
como humanidad en su conjunto. Por supuesto que tal enfoque pone inmediatamente en el centro del debate la centralidad del estado como actor exclusivo o preponderante del sistema internacional.

En este sentido, la desconfiguración misma del sistema estatal a raíz del aparente desdibujamiento del estado como actor central del sistema internacional actual exige una cuidadosa revisión, no sólo de las causas que han generado este fenómeno, sino también de los procesos de interacción contemporánea entre actores internacionales (más allá del Estado) porque ahí radican, en gran medida, las bases para la explicación del fenómeno actual de la paradiplomacia y sus implicaciones.

De este modo, sin negar las limitaciones que impone a la cooperación internacional la idea de soberanía y el interés nacional, podemos reconocer que, al mismo tiempo, los desafíos de la globalidad se traducen en una mejor disposición a la cooperación y la búsqueda de soluciones conjuntas ante problemas que no reconocen límites establecidos por las fronteras nacionales o los ámbitos soberanos. Esto es algo que los responsables del diseño de política exterior de todos los estados necesitan reconocer con urgencia en la fase actual del desarrollo del sistema internacional.

Esto no significa que los actores internacionales estatales van a renunciar definitivamente a sus derechos soberanos, y con ello a la defensa de sus intereses nacionales, pero sí, al menos, que van a mostrar, como de hecho ya están haciendo algunos, una mejor disposición a la búsqueda de soluciones conjuntas y negociadas a los conflictos propios del sistema internacional globalizado, donde se encuentran las bases para una concepción ampliada de política exterior hoy en día, que se puede implementar por vías más allá de los conductos oficiales del estado. Esta concepción necesita ir mucho más allá del enfoque miope de las teorías de corte realista, que se centran exclusivamente en la idea del interés propio, independientemente de las consecuencias que éste genere para el resto del sistema internacional. El problema, no obstante, sigue estando tanto en quién y en qué se propone así en cómo se implementa lo propuesto a nivel de sistema. 
A partir de este planteamiento es posible y necesario repensar la política exterior de los estados, ya no exclusivamente como el diseño de estrategias para la acción interestatal en defensa del interés propio por vías diplomáticas tradicionales, sino como parte de un esfuerzo coordinado por sentar las bases para el establecimiento progresivo de una auténtica comunidad internacional en la que el estado podría seguir siendo, incluso, primus inter pares, pero, de ninguna manera actor exclusivo del escenario internacional o centro monopólico de actividad diplomática.

El desdibujamiento del estado como actor central del sistema permite entonces una actividad de intercambio entre actores sub-estatales, supra-estatales o no estatales del sistema (paradiplomacia) como participantes activos (y no sólo como receptores pasivos) en la configuración del sistema.

Para poder repensar de manera más eficiente tanto la actividad estatal en materia de diseño de política exterior en la actualidad, como la participación de nuevos entes interactuantes en el proceso de configuración del sistema internacional en su conjunto, necesitamos reconsiderar, aunque sea brevemente, los orígenes mismos del sistema de estados soberanos y su contexto histórico-geográfico, para así entender mejor su génesis, su fisonomía y su fisiología, de modo tal que podamos reinterpretarlo como un desarrollo histórico concreto, siempre en proceso de transformación y no como una forma única e inalterable de sistema internacional que prevalece básicamente inalterado en cualquier latitud y en cualquier época $;{ }^{20}$ de esta forma, la idea de paradiplomacia puede hacer mucho mejor sentido.

\footnotetext{
20 Concretamente, este es uno de los propósitos declarados de la naciente escuela china de las relaciones internacionales. Ver Zhang (2015).
} 


\section{Orígenes del sistema internacional moderno}

Esta es la parte del periplo histórico que algunos podrían considerar totalmente innecesaria. Como historiador de las relaciones internacionales, sin embargo, me parece indispensable para una comprensión cabal de la estructura y del funcionamiento, e incluso de la especificidad del sistema internacional contemporáneo. Parafraseando al maestro Ortega \& Gasset, bien podríamos decir que el sistema internacional no tiene naturaleza propia, sino historia. La idea misma de un sistema internacional es hija de la modernidad occidental ${ }^{21}$ y es ahí donde conviene empezar a estudiarla. Sin embargo, es preciso señalar que esta idea no resulta impensable fuera del contexto temporal de esta modernidad. ${ }^{22}$

Es cierto que el sistema internacional se gestó como resultado de una experiencia histórico-concreta, que fue la ruptura del mundo de la cristiandad a partir del primer cuarto del siglo XVI, como resultado de los conflictos entre las altas jerarquías del sistema (el emperador y el papa) y el creciente margen de acción que obtuvieron en ese contexto los reyes y otros miembros de la alta nobleza. Ahí empezó a desarrollarse el sistema actual, en la medida en que diversos analistas, desde distintos campos disciplinarios, con frecuencia sin haber tenido la intención de hacerlo, abonaron de manera gradual a su caracterización. Es por ello que el pensamiento ortodoxo en esta materia pretende limitar la idea de sistema internacional (y de hecho, la idea de relaciones internacionales en su conjunto) a esa experiencia histórico concreta y su evolución hasta nuestros días. No obstante,

\footnotetext{
21 Ciertamente la idea misma de modernidad no está exenta de controversia. Difícilmente vamos a encontrar un consenso amplio en relación con su significado o su alcance temporal. Sin embargo, la idea puede pensarse bien sea como un lapso de tiempo o como un paradigma. Hay razones sólidas para pensarla como experiencia temporal a lo largo del siglo XVI, pero es sobre todo en términos paradigmáticos que proyecta su influencia sobre la idea de un sistema internacional y, muy concretamente en el proceso de secularización de la política que allanó el camino para el surgimiento del Estado moderno.

22 Es importante hacer esta referencia porque deja abierto el camino para la consideración y el análisis de experiencias internacionales en un horizonte histórico de mayor alcance. Habrá que justificar, por supuesto, que tal ejercicio es no solo provechoso, sino también válido en términos epistemológicos.
} 
hay que aprender a ponerla en un contexto más amplio del devenir humano-social, para poder visualizar sus nexos con otras experiencias históricas de la misma naturaleza, sin que ello justifique, en forma alguna una homogeneización simplista de la historia de lo internacional. ${ }^{23}$

En sus orígenes, la incipiente idea de un sistema internacional aparece como un ensamble de Estados soberanos, ${ }^{24}$ por lo que resulta indispensable referir el proceso de surgimiento mismo del Estado soberano como prerrequisito para hablar, tanto de política exterior y diplomacia, como de sistema internacional (el ámbito en el que se implementa, a través de la diplomacia, la política exterior de los estados).

Tal como hemos señalado, la idea de un sistema internacional moderno está indisolublemente vinculada a la idea del Estado soberano, cuya existencia sugiere la imposibilidad práctica de una autoridad supraestatal y, por ende, condiciona un ambiente anárquico y de hostilidad recíproca entre los integrantes del conjunto, que suele resolverse por medio de la acumulación de recursos de poder. Pero ¿cómo surge ese ensamble de Estados soberanos del sistema contemporáneo? La mayor parte de los analistas especializados en relaciones internacionales ven el origen del sistema internacional actual en un proceso multifactorial que gradualmente llevó a la escisión del mundo de la cristiandad entre los siglos XVI y XVII. Entre las causas frecuentemente mencionadas para explicar este proceso se encuentran:

a) La tradicional rivalidad entre los papas y los emperadores que se disputaban el control efectivo de la Europa cristiana.

\footnotetext{
23 En su acepción flexible, el concepto de lo internacional se refiere, como ya hemos sugerido, a toda forma de interacción entre grupos políticamente independientes a los que se aplica el nombre genérico de actores internacionales, pero que en cada época histórica tienen sus propias características distintivas.

${ }^{24}$ El estado soberano, comunidad política que no reconoce a otra autoridad por encima de sí misma, representa una novedad en ese contexto, hasta entonces caracterizado por una rígida jerarquía dual (Papa y Emperador) a la que todos están sometidos. Sin embargo, la idea no es nueva del todo; las polis griegas o sumerias, y los estados combatientes chinos o indios, por sólo citar algunos casos practicaban formas soberanas de organización e interacción.
} 
b) El creciente poderío de los reyes como consecuencia de la disputa anterior.

c) El movimiento de Reforma eclesiástica encabezado por Martín Lutero, cuestionando la autoridad papal, las formas de interpretar y practicar la doctrina cristiana por parte de la iglesia católica y las subsecuentes guerras religiosas a las que dio lugar.

d) La transformación de la estrategia militar gracias a la innovación que representaron las armas de fuego.

e) La consolidación del espíritu renacentista, inspirado en un renovado humanismo de perfil más laico (aunque todavía no del todo liberado de la influencia religiosa).

f) El progreso del enfoque de la ciencia resultante de ese espíritu renacentista.

g) La subsecuente secularización de la política.

h) El desarrollo del capitalismo (que inicia a mediados del siglo XII, con un incremento de la otrora limitada actividad comercial, y viene hasta nuestros días, con una decisiva transformación del modo de producción, pasando por la revolución industrial orientada fundamentalmente a la eficiencia productiva generadora de mercancías destinadas al mercado).

No son ciertamente las únicas causas que transforman al mundo medieval europeo, pero están sin duda entre las más relevantes y constituyen un buen punto de partida para el análisis de la idea misma de relaciones internacionales contemporáneas y sus implicaciones teórico-metodológicas.

Hablar de la unidad del mundo medieval es obviamente engañoso. Hay un cierto nivel de unidad en ese ámbito, derivada de la condición religiosa imperante, puesto que el dominio cultural de la iglesia católica era manifiesto, pero en términos políticos y económicos el mundo medieval es un escenario visiblemente fragmentario en el que, literalmente, cientos de distintas entidades de los más diversos tamaños pueblan el territorio, satisfacen primordialmente sus propias necesidades económicas y son regidas por un complejo sistema jerárquico comandado por la nobleza y el alto clero, todos bajo la égida papal e imperial, sin que los límites entre ambos niveles de autoridad 
estén claramente definidos, lo que de hecho impidió la creación de un poder central suficientemente fuerte y sólido, capaz de controlar a la totalidad del conjunto.

De este modo, la ruptura medieval se da más en términos religiosos y culturales que políticos y económicos, ya que, de hecho, en política y economía empieza un proceso inverso de concentración y ensanchamiento de las diversas entidades que va a dar paso al surgimiento del Estado soberano europeo y, eventualmente, -casi trescientos años después-al estado nacional.

Cuando uno lee historia 'universal' tradicional, parece como si todos estos procesos se hubiesen gestado de manera endogámica y exclusiva en Europa Occidental. En términos generales, los europeos han sido reacios a reconocer sus deudas históricas con otros pueblos y civilizaciones. La transformación del medioevo europeo hubiera sido prácticamente imposible sin el impulso que recibió del contacto con el mundo musulmán, con la cultura bizantina en el Medio Oriente y con las culturas (y los productos) de India y China en el lejano oriente.

El caso es que dos siglos de contacto con todos ellos a través de la experiencia de las Cruzadas, entre finales del siglo XI y el último cuarto del siglo XIII, dejaron importantes legados en los ámbitos comercial, cultural y científico para el ulterior desarrollo de la Europa moderna. En su afán por actualizarse para poder seguir participando del atractivo comercio con el Medio Oriente, una vez que fueron expulsados militarmente de esa región, los europeos aprovecharon toda la experiencia acumulada del periodo y se modernizaron.

Esto permitió no sólo un incremento de su actividad comercial, sino la adopción de materiales y técnicas que revolucionaron el ámbito europeo (la imprenta y la pólvora son solo dos claros ejemplos de lo que ocurrió, y la idea misma de modernidad está estrechamente vinculada a su uso). El desarrollo de la ciencia, considerado como la gran contribución europea para el desarrollo de la modernidad, habría sido imposible sin las aportaciones de las matemáticas de la 
India, la ciencia musulmana e incluso, la filosofía china. Ese mismo proceso de modernización permitió, también gracias al desarrollo de la ciencia, un creciente cuestionamiento de las bases religiosas que sustentaron a la cristiandad y su gradual laicización.

Entre las implicaciones teórico metodológicas más importantes en relación con el análisis del surgimiento del Estado soberano y la configuración del sistema internacional está la idea de que éste último, "propiamente hablando" sólo puede ser pensado como un ensamble de Estados soberanos y que su caracterización sólo puede hacerse sobre la base de un ambiente hostil y anárquico, en el que los propios participantes se van a oponer irremediablemente al surgimiento de una entidad supranacional que regule la interacción entre todos ellos, como habían intentado hacer los papas y los emperadores.

En este nuevo contexto, la posibilidad de la cooperación, como ya hemos señalado, es siempre limitada (subordinada, de hecho al interés de los miembros más poderosos del sistema) y, la política exterior tiene que ser, inevitablemente pensada en términos egoístas, como un plan de acción para salvaguardar el interés nacional, por lo cual siempre debe estar controlada por el aparato estatal.

Son principalmente los juristas quienes han podido ver y entender con mayor claridad las implicaciones que tiene el representarnos al sistema internacional como un ensamble de Estados soberanos: Kelsen (1934) observa atinadamente que "la idea de soberanía estuvo ligada bistóricamente al fortalecimiento de la monarquía absoluta centralista, pero aún en el actual Estado democrático se la utiliza con fines políticos, creando confusión y presentando deseos políticos como verdades absolutas" (p. 148). Una de esas "verdades absolutas" sugiere que el estado de anarquía es concomitante con la idea de sistema internacional, lo que permite pensar que la política exterior del cualquier Estado sólo puede ser un plan de promoción de los intereses de cada Estado y que sólo puede ser exitosa cuando está firmemente controlada por el poder soberano. 
En términos histórico-concretos, es el trabajo de Jean Bodin, Los seis libros de la república, aparecido en $1576,{ }^{25}$ el que sienta las bases de la reflexión sobre la naturaleza del poder que debe regir a una comunidad política: el poder soberano. Por supuesto que la obra refleja con toda claridad el frágil y explosivo escenario político tanto de Francia como de Europa durante el siglo XVI, desde la época del reinado de Francisco I y sus luchas con el emperador austriaco, Carlos V, hasta la de la muerte de su nieto Francisco II y la regencia de Catalina de Medici. Una época de fuertes presiones tanto internas como externas que amenazan con desintegrar al aún incipiente reino francés. En ese contexto, las palabras de Bodin no sólo cobran pleno sentido, sino que se puede apreciar en ellas la clara influencia que habrían de ejercer en Hobbes a mediados de la siguiente centuria:

La soberanía es el poder absoluto y perpetuo de la República (...). La soberanía no es limitada, ni en poder, ni en responsabilidad, ni en tiempo (...). es necesario que quienes son soberanos no estén de ningún modo sometidos al imperio de otro y puedan dar ley a los súbditos y anular o enmendar las leyes inútiles (...). Dado que, después de Dios, nada hay mayor sobre la tierra que los príncipes soberanos, instituidos por Él, como sus lugartenientes, para mandar a los demás hombres, es preciso prestar atención a su condición para, así, respetar y reverenciar su majestad con la sumisión debida, y pensar y hablar de ellos dignamente, ya que quien menosprecia a su príncipe soberano menosprecia a Dios, del cual es su imagen sobre la tierra. (2015, [en línea]).

La línea de argumentación que abre Bodin en su texto es determinante para la configuración del nuevo sistema internacional que se gesta con la fragmentación de la cristiandad. Ahí donde la norma de interacción entre actores internacionales era la jerarquía y la subordinación a una autoridad soberana superior, se despliega la idea de una igualdad soberana que inviste a la relación entre las partes de

25 La obra puede consultarse en la biblioteca virtual de la UNAM, en www.juridica.unam. $\mathrm{mx}$ 
una condición novedosa, la cual cambia la dinámica misma del viejo sistema y genera las bases para uno nuevo visiblemente reformado: el sistema internacional moderno.

El proceso de inestabilidad que se generó con la reforma luterana durante los últimos años de la segunda década del siglo XVI vendría a culminar más de un siglo después, con la celebérrima firma de los tratados de Münster y Osnabrück en Westfalia en 1648. Este evento termina con la famosa guerra de los 30 años y formalmente da inicio a la era del sistema internacional moderno, conformado por Estados soberanos. Es a raíz de este proceso que empezamos a hablar de política exterior en el sentido moderno, como una responsabilidad del Estado (concretamente representado por su monarca) para tratar con sus pares a través de sus representantes diplomáticos.

Curiosamente, los teóricos de las relaciones internacionales, que no van a aparecer como tales, sino hasta el término de la Primera Guerra Mundial en 1919, reconocen en Westphalia el parteaguas para hablar de un sistema internacional propiamente dicho, aunque los estados nacionales no se empiezan a configurar como tales, sino hasta la primera mitad del siglo XIX. No obstante, para fines de análisis, la convención es pensar en este sistema desde el año 1648, como un sistema predominantemente interestatal, con miembros que se reconocen formalmente en un plano de igualdad jurídica y soberana. ${ }^{26}$

En estos términos, el sistema es una aparente novedad histórica, porque en los escenarios 'internacionales' la norma, desde la antigüedadhabía sido el esquema jerárquico- tributario, donde los miembros reconocen a uno de los integrantes como poder hegemónico con autoridad soberana y capacidad para regular la interacción entre todos ellos El caso de las ciudades-estado mesopotámicas y griegas es considerado normalmente como una notable excepción, habida cuenta del trato aparentemente igualitario que se daban entre ellas, pero siempre bajo la tendencia hacia el establecimiento de un poder

26 Ver, Teschke, B. (2003). 
hegemónico (que finalmente logró, en el caso griego, aunque sólo de manera efímera, Filipo II de Macedonia con el apoyo de su hijo Alejandro Magno después de la batalla de Queronea, ${ }^{27} 338$ años antes de Cristo).

\section{El sistema westfaliano de estados soberanos}

El esquema de la igualdad jurídica formal entre los miembros del sistema instaurado después de la Paz de Westfalia representa para los puristas $^{28}$ de nuestra disciplina el único que merece, en sentido estricto, el nombre de sistema internacional y es el que históricamente se fue imponiendo de manera gradual en el curso de los últimos tres siglos y medio hasta alcanzar, por primera vez en la historia, una dimensión auténticamente planetaria a partir del término de la Guerra Fría. De hecho, ya durante ésta, los bloques contendientes estaban conformados por estados de filiación nacional, aunque el objeto mismo de la contienda (por lo menos desde el punto de vista soviético) era trascender ese modelo para instaurar una comunidad internacional de trabajadores. Pero resulta definitivamente engañoso pensar que el sistema estaba predominantemente integrado por estados nacionales antes de la Segunda Guerra Mundial.

Si bien es cierto que con la desintegración de los imperios zarista, alemán y otomano al término de la Primera Guerra Mundial, se había intentado redefinir sus territorios en base a ese modelo (el del estado nacional) según la visión del Presidente Woodrow Wilson de un territorio propio para cada pueblo, lo cierto es que la escena política internacional seguía dominada hasta ese momento por la idea imperial, con Francia e Inglaterra luchando no sólo por preservar sino,

\footnotetext{
27 Famosa por su importancia histórica como hecho fundamental para el inicio de la hegemonía de Macedonia en la Hélade, y por ser considerada como el fin de la falange clásica e inicio de la supremacía de la falange macedónica. (Anábasis Histótica, [en línea]).

28 No empleo el término en sentido peyorativo; este enfoque tiene su razón de ser, está centrado en la especificidad del sistema internacional moderno, lo que, sin lugar a duda tiene sentido. Mi única objeción es que limita el horizonte histórico de reflexión sobre una temática (la internacional) que, estudiada desde una perspectiva menos rigorista, ofrece un campo visual más vasto y permite una reflexión teórica mucho más amplia y provechosa.
} 
de hecho, por acrecentar sus dominios, mientras que los japoneses intentaban crear el suyo propio.

Los mismos estadounidenses habían tenido un intenso debate doméstico sobre su condición imperial luego de la aplastante victoria que tuvieron sobre España en 1898, de la cual obtuvieron control territorial directo sobre Cuba, Puerto Rico, Las Filipinas y Guam. Sin embargo, la experiencia histórica ya les había mostrado lo costosa que resulta la política del control imperial directo, por lo que, guiados por su espíritu pragmático, optaron por la defensa del modelo del ensamble de estados soberanos, siempre y cuando cada uno de ellos estuviese regido por un sistema democrático representativo y liberal, y siguiese una política económica de libre mercado, aspiración que los norteamericanos defienden y promueven empecinadamente y que, de hecho, se convirtió en variable definitoria del curso de la historia mundial contemporánea durante la mayor parte del siglo XX.

Sin embargo, a pesar de la presión ejercida por Estados Unidos al término de la Primera Guerra Mundial, el estado nacional era todavía en 1945 un ideal que, en sentido estricto, pocos habían alcanzado. Desde esta perspectiva, incluso aquellos que ya tenían la fachada de estados nacionales, (caso concreto de las repúblicas latinoamericanas) disponían de limitada capacidad real para el diseño o la implementación de su propia política exterior y el ejercicio de su diplomacia. Es quizá por ello que diversos analistas señalan con frecuencia la distancia que separa a la teoría de la práctica.

No será realmente sino hasta que se inicia el periodo de descolonización a finales de los años cuarenta del siglo pasado - en gran medida debido a la determinación y empeño de la política exterior norteamericanaque el escenario empieza a poblarse predominantemente con estados nacionales (o, mejor dicho, con intentos por conformarlos).

Es claro que, en este sentido, la lucha contra la instauración del modelo soviético de una sociedad sin clases (y sin estados nacionales) llevó a los norteamericanos a confrontar a sus propios aliados, forzando la mano de los ingleses y los franceses para acelerar los procesos de 
descolonización, con el fin de fomentar la creación de nuevos estados nacionales 'independientes' y 'soberanos ${ }^{29}$ moldeados a su imagen y semejanza.

¿Por qué entre comillas? Porque todos los críticos especialistas en política internacional de la época aseguraban que Estados Unidos sólo deseaba la formalidad de la fachada del estado nacional para poder imponer a trastienda, entre los miembros del sistema, las condiciones que hicieran operativo al sistema en términos favorables para sus propios intereses, (tal como habían hecho los ingleses durante el periodo de formación de las repúblicas latinoamericanas) es decir, impulsó a la iniciativa privada, el libre mercado, la democracia representativa liberal, la promoción de la idea de los derechos humanos y la propensión al consumo (de productos norteamericanos) en un mercado libre de trabas. La tarea no era nada fácil; el resto del mundo parecía dar prioridad, por lo menos en ese momento, a la idea de la seguridad y la distribución equitativa de la riqueza, antes que a la idea de la libertad individual, tan cara al proyecto norteamericano.

\section{Un efecto contraproducente}

Dice un refrán popular que el camino al infierno está plagado de buenas intenciones. Según los encargados del diseño e implementación de la política exterior norteamericana, Washington no ha tenido otra intención desde la época de su ascenso como potencia mundial, que la de expandir el reino de la democracia y la libertad para que todos y cada uno de los pueblos de la tierra, regidos por su propio estado, puedan aprovechar sus beneficios.

Cuando los marines invadieron el Puerto de Veracruz en 1914, supuestamente tenían la buena intención de forzar la salida de Victoriano Huerta del gobierno y apoyar al movimiento constitucionalista de

\footnotetext{
29 En 1973, Raymond Aron publicó un libro sobre los Estados Unidos en la política mundial titulado La república imperial. Este autor describió así una contradicción que no pudo resolver la Roma clásica: una forma de gobierno republicana que, además, ejercía imperium sobre gran parte del mundo entonces conocido (Quagliotti de Bellis, 2007).
} 
Venustiano Carranza para la reorganización de un México moderno, ${ }^{30}$ pero ni Carranza, ni el pueblo de México vieron así las cosas; aún no acababan de cicatrizar las heridas de la guerra de 1846-1848, cuando los "gringos" ya nos estaban invadiendo de nueva cuenta. El sentimiento anti-yanqui en el país no es todavía del todo cosa del pasado (López Vega, 2014).

Del mismo modo los norteamericanos se vienen esforzando, mucho más visiblemente a partir del término de la Segunda Guerra Mundial, por reconfigurar el sistema internacional siguiendo el ideal del estado nacional, siempre gobernado por regímenes de democracia representativa y liberal, garante del libre mercado. Pero igual que en México en 1914, sus esfuerzos no siempre son apreciados como gestos de buena voluntad por promover la democracia y la libertad. Al contrario, en la mayor parte de los casos le han ganado la reputación de intervencionistas y neoimperialistas a todo lo largo del siglo XX.

El proceso de promoción de la democracia liberal resultó particularmente difícil en el contexto de la Guerra Fría, porque los soviéticos tenían su propia propuesta de organización y su modelo de proyección internacional, que por razones históricas que no son demasiado difíciles de entender, parecía ser más atractivo a los ojos de las masas depauperadas por los procesos coloniales, de tal forma que, a pesar de los recursos invertidos por los norteamericanos por "educar" para

\footnotetext{
30 Las causas de ese lamentable incidente, sin duda fueron varias, pero no parece que el interés principal de los norteamericanos en este caso haya estado, en evitar la influencia del Imperio Alemán en el nuevo gobierno de México. Hay abundante literatura para demostrar que, el incidente que antecede la invasión del puerto de Veracruz el 21 de abril de 1914 fue la detención de una nave estadounidense en Tampico dos semanas antes (el 9 de abril), pretexto que usaron los norteamericanos para presionar al gobierno de Huerta con reclamos excesivos. Atacaron Veracruz porque supieron de un buque, El Ipiranga que llevaba un cargamento de armas que el gobierno mexicano, por entonces enfrascado en una fratricida guerra civil, había comprado a los alemanes (no que los alemanes estuvieran enviando como apoyo a México). No hay indicio alguno de que el gobierno mexicano estuviera planeando ninguna forma de ataque contra Estados Unidos o que pensara aliarse con Alemania en una guerra que ni siquiera había comenzado. La propuesta que hizo el gobierno alemán a Carranza de recuperar los territorios perdidos en la guerra de 1846-48, a través del célebre telegrama Zimmermann, no se formuló sino hasta enero de 1917, casi tres años después de la invasión de Veracruz.
} 
la democracia y el libre mercado, una vez ganada su independencia, los nuevos estados nacionales siempre parecían gravitar más naturalmente hacia la esfera de influencia soviética que hacia el lado norteamericano, a veces, incluso de manera indirecta, a través de políticas públicas encaminadas a proteger a los sectores sociales más débiles.

Incluso después del surgimiento del movimiento de los no alineados a mediados de la década de los cincuenta del siglo pasado, que específicamente rechazó la idea de seguir a pie juntillas el modelo soviético por considerarlo igualmente impositivo, los nuevos estados tendían a diseñar sus políticas públicas más hacia la izquierda de lo que resultaba conveniente para los intereses de Estados Unidos. Los nuevos estados nacionales, que debían estar agradecidos por el apoyo estadounidense para su conformación como tales, empezaron a convertirse en una molestia para los encargados del diseño de la política exterior norteamericana y sus implementadores en el cuerpo diplomático de ese país. ${ }^{31} \mathrm{Al}$ parecer, algunos de esos nuevos actores empezaron a tener la osadía de pensar que su soberanía efectivamente les daba el derecho de forjar su propio destino mediante el diseño de sus propias políticas independientemente de cómo pudieran afectar los intereses de Estados Unidos.

Ya para principios de la década de los setenta del siglo pasado, los norteamericanos enfrentaban una fuerte oposición, muchas veces en bloque, de los recientemente creados estados nacionales de pasado colonial inmediato en los foros internacionales. El clímax de la tensión se alcanzó en 1974. El año anterior los países no-alineados habían hecho un importante llamado para la construcción de un Nuevo Orden Económico Internacional (NOEI) que permitiera un desarrollo más equilibrado y más justo de las regiones menos favorecidas del planeta.

\footnotetext{
31 Experiencias como las de Jacobo Arbenz, en Guatemala (1954); Mohammad Mossadeq, en Irán (1953), y Patricio Lumumba en la República democrática del Congo (1960), o incluso Salvador Allende en Chile (1973) muestran claramente que los norteamericanos no estaban dispuestos a tolerar ningún esfuerzo reformista.
} 
$\mathrm{Al}$ año siguiente, Naciones Unidas tuvo una sesión de debate especial sobre el tema y aun frente a una decidida oposición de Estados Unidos, la Asamblea General aprobó una declaración para el establecimiento del NOEI. Se concedió alta prioridad al tema del desarrollo, pero el G-77 puso el énfasis en las cuestiones de la soberanía y la justicia. Los estados deberían tener la libertad para hacer lo que quisieran en términos internacionales sin interferencias externas, elegir el régimen de desarrollo que consideraran más conveniente y ejercer 'plenos y permanentes derechos soberanos (...) sobre todos sus recursos y actividades económicas. Estados Unidos, que habían soñado bajo la administración Truman ser líderes del proceso mundial contra la pobreza eran ahora fustigados por defender los derechos de las grandes corporaciones y empresas (Mazower, 2012, pp. 303-304).

\section{La reacción de la política exterior norteamericana}

Uno de los primeros en lanzar señales de alerta ante esta 'anormalidad' fue el embajador de Estados Unidos ante la ONU, Daniel Moynihan, quien desató una fuerte controversia con un artículo publicado en Commentary 59 con el título de "Estados Unidos en la oposición", denunciando la embestida de los no-alineados contra las posturas estadounidenses en los foros mundiales, y obligando a Washington a un repliegue táctico (Mazower, 2012). Para agravar aún más las cosas, por esa misma época, la Comunidad Económica Europea parecía querer reevaluar su relación con los países del Tercer Mundo y unir fuerzas con ellos en los foros internacionales (especialmente en la UNCTAD), haciendo en alguna medida a un lado a sus socios norteamericanos. Fue entonces cuando la política exterior norteamericana decidió hacer una revisión puntual de sus objetivos así como de los mecanismos para alcanzarlos y, al parecer, decidió que la idea de estados nacionales soberanos y democráticos no era tan conveniente como inicialmente habían creído, porque los pueblos a los que se había brindado la oportunidad de organizarse según los cánones de este modelo, sencillamente no estaban cabalmente preparados para entender y aprovechar sus beneficios. 
Los norteamericanos, que habían hecho malabares para defender la idea del estado nacional soberano, incluso confrontando a sus propios aliados o apoyando decididamente a regímenes abiertamente antidemocráticos, siempre y cuando mantuvieran la viabilidad del estado nacional del lado de la zona de influencia estadounidense, empezaron entonces a cambiar de estrategia y a promover la idea de la menor interferencia estatal posible en las cuestiones de la vida pública de todas las sociedades del mundo. Es decir, comenzaron a tratar de debilitar a los aparatos estatales de cada estado nacional con la intención de permitir que una sociedad civil emergente fuera buscando formas más cómodas de relacionarse con el exterior. ${ }^{32}$

Friedman (1999) ha caracterizado muy claramente los objetivos del programa neoliberal, a través de la metáfora de la camisa de fuerza dorada en los términos siguientes:

Para poder ponerse la camisa de fuerza dorada, un país debe adoptar, o bien ser percibido moviéndose en la dirección de las siguientes reglas de oro: hacer del sector privado el motor primario del crecimiento económico, mantener una baja tasa de inflación y estabilidad de los precios, reducir el tamaño de la burocracia pública mantener un presupuesto lo más equilibrado posible, si no superavitario, eliminar o reducir los aranceles sobre los productos importados, remover las restricciones sobre sobre las inversiones foráneas, quitar el camino las cuotas y los monopolios domésticos, aumentar las exportaciones, privatizar las empresas públicas, desregular los mercados de capital, volver convertible la propia moneda, abrir las propias industrias y los mercados accionarios y de bonos a la inversión extranjera, desregular la economía interna para promover un mayor grado de competencia, eliminar la corrupción institucional, los subsidios y los contragolpes tanto como sea posible, abrir los sistemas bancarios y de telecomunicaciones a la inversión privada y la competencia así como permitir a

\footnotetext{
32 Genéricamente hablando, el proceso inició la gestación de lo que hoy conocemos como neoliberalismo, doctrina dominante que dio impulso vital al proceso de globalización característico de las últimas tres décadas.
} 
los ciudadanos elegir entre toda una gama de opciones de fondos para pensiones y mutualistas. Cuando se junten todas estas piezas, tendremos la camisa de fuerza dorada (pp. 86-87).

Me parece evidente que el resultado inevitable de la aplicación de este programa es un creciente debilitamiento de las estructuras estatales clásicas y un acotamiento del principio de la soberanía. Cabría preguntarse si el programa neoliberal fue un diseño intencional de la política exterior norteamericana para afianzar su posición hegemónica en el mundo o no, pero los resultados son inequívocos, el poder estatal no es el mismo desde entonces y eso ha beneficiado al liderazgo americano del sistema internacional (lo que, por lo menos en alguna medida hace la hipótesis plausible).

En varios casos, los norteamericanos empezaron incluso a retirar su apoyo a los regímenes dictatoriales y a impulsar políticas de promoción de los derechos humanos, privatización, adelgazamiento de la estructura estatal, reducción de gastos en el sector social y, sobre todo, adopción de políticas de libre circulación de mercancías y capitales, es decir, iniciaron un ataque frontal contra las estructuras estatales clásicas, no con la intención de desaparecer a los estados nacionales del escenario internacional, por supuesto, sino simplemente para debilitarlos como actores unitarios del sistema, al punto en que ni siquiera a través de su acción colectiva, las autoridades estatales pudiesen representar un reto al liderazgo mundial norteamericano.

Este mecanismo de desagregación de instancias estatales, es decir, de fragmentación de los elementos de poder del Estado, dio paso a un progresivo fortalecimiento de la sociedad civil en varios países y, con él, a la ilusión de una mayor democracia. Los actores sub-estatales (que ciertamente siempre habían existido) no sólo empezaron a proliferar, sino de hecho a ganar cuotas de poder reales, mismas que empezaron a ejercer con gusto, en detrimento del poder estatal soberano, cada vez más mermado en varias partes del mundo, al punto que, ya a finales de los ochenta, Drucker (1990) podía preguntarse, sin que sonara a mera retórica: "¿Nos encontramos en realidad al final de un periodo en que el Estado no reconocía límites ni respecto a sus actividades 
ni respecto a su capacidad para el cambio social, ni respecto a sus recursos? Hay algunos signos precursores. Al final, los políticos saben que ya nadie cree en sus promesas" (p. 117).

El proceso se aceleró de manera significativa al término de la Guerra Fría, una vez que el bloque soviético desapareció como tal del escenario internacional y la idea misma de soberanía fue colocada en el banquillo de los acusados y señalada como un obstáculo al progreso y cumplimiento de las metas de la modernidad. Esta idea, que había sido pilar y sustento para el surgimiento del sistema internacional moderno, era ahora señalada como obstáculo para el desarrollo de una auténtica sociedad internacional.

Bajo la égida del programa neoliberal, el ataque contra las estructuras estatales, y por ende contra la idea tradicional de soberanía, se agudizó. Aunque la imagen del estado nacional como actor del escenario internacional permanece vigente, el discurso sobre nuevos actores y nuevas formas de interacción entre ellos empezó a dominar la academia. A partir de estos acontecimientos comenzó a florecer, entre otros, el desarrollo de la paradiplomacia:

El advenimiento de actores no estatales, como las organizaciones gubernamentales y no gubernamentales, individuos o empresas transnacionales ha modificado nuestras percepciones del derecho internacional contemporáneo. Los actores no estatales se han vuelto una constante en las relaciones internacionales actuales y juegan un papel fundamental en todas las áreas del derecho internacional y los intentos de regulación. Algunos temas de controversia y debate en conexión con la participación de actores no estatales en el sistema internacional incluyen: la atribución de personalidad legal independiente y las capacidades legales concomitantes, la legalidad de estos actores en los procesos de negociación internacional, incluyendo la responsabilidad de los actores no estatales en los sistemas legales nacionales e internacionales y la relativa falta de protección judicial para ellos (ResearchGate Brill Academic Publishers, [en línea]). 
En este, como en la mayoría de los casos, la práctica va dos pasos adelante de la teoría (y varios más delante de la acción reguladora). En el contexto dinámico y cambiante del escenario internacional globalizado, el flujo de interacción entre un número creciente de actores no estatales ha rebasado, con mucho, la capacidad de un aparato estatal debilitado por la acción de las políticas neoliberales para mantener control monopólico, tanto del diseño como de la implementación de la política exterior.

Hoy en día, provincias o subregiones de diversos estados nacionales, incluso ciudades individuales, empresas, partidos políticos o asociaciones civiles y religiosas promueven directamente sus intereses en el exterior. Incluso, dentro del propio sector gubernamental, diversas instancias de los poderes legislativo, ejecutivo y judicial operan con frecuencia al margen de sus respectivos ministerios o secretarias de relaciones exteriores, corriendo programas paralelos a los de la diplomacia oficial en sus respectivos países.

Ciertamente, esto puede contribuir a hacer más expedito y fluido el trato entre todos ellos y sus contrapartes en el extranjero y, de este modo, fortalecer el proceso de construcción de una sociedad internacional más sólida y funcional, pero sin duda, ha sido favorecido por el proceso de debilitamiento de las estructuras estatales que los norteamericanos emprendieron desde la década de los setenta del siglo pasado, en respuesta a las actitudes desafiantes y confrontacionales de los nuevos estados nacionales, reacios a aceptar pasivamente la imposición del modelo americano.

Hoy en día, aun cuando varias sociedades civiles han votado en favor de gobiernos de izquierda que se oponen a la aplicación irrestricta de las políticas neoliberales, la debilidad estructural de sus estados aunada a la fortaleza de la inercia del sistema capitalista impide cambios significativos de rumbo. En este sentido, algunos de los retos más significativos para el nuevo sistema internacional en gestación es, precisamente, el intento de fortalecer de nueva cuenta a los aparatos estatales debilitados durante la fase globalizante del sistema de la post Guerra Fría, es decir, restaurar la idea suprema de la soberanía 
absoluta. De este modo, por ejemplo la Rusia de Putin, Irán de los ayatolás, la China del Partido Comunista, la Venezuela de Chávez, por sólo señalar los más visibles, representan desafíos que el sistema norteamericano trata de combatir.

La academia norteamericana, por su parte, ha hecho enormes esfuerzos, no sólo por explicar, sino por justificar este progresivo debilitamiento del estado nacional soberano, argumentando que, en gran medida facilita los procesos de gobernanza internacional:

En términos históricos, siempre han sido los actores no estatales los que se empeñan en traspasar las fronteras nacionales. Esto ha sido especialmente cierto en el contexto económico, por ejemplo, con las Compañías de Indias en los siglos XVII y XVIII, o los procesos de colonización del siglo XIX. Pero también ha sido cierto de movimientos sociales como la Cruz Roja, los movimientos contra la tortura o la esclavitud, incluso aquellos que promovieron instituciones internacionales como la Sociedad de las Naciones o la ONU y hasta la Unión Europea (WorldGovernance.org [en línea]).

El argumento puede ser válido, pero el debilitamiento en sí de las estructuras estatales también puede ser visto como estrategia de la política exterior norteamericana para imponer su modelo en el proceso que busca la homogeneización del sistema internacional. Desde este punto de vista, la idea de la gobernanza mundial pierde parte de su atractivo cuando se presenta como una imposición de la política exterior de Estados Unidos.

En otro sentido, pero con trasfondo similar, según explican Rojo, Salomone \& Zapata (1998), Jean-François Lyotard, uno de los pensadores más prominentes dentro de las corrientes llamadas postmodernas, asegura que en su proceso actual de reajuste operativo, apoyado por el desarrollo de la tecnología, el capitalismo ha propiciado importantes cambios en el modo de operar del Estado, haciendo que las funciones de regulación escapen cada vez más de sus administradores, mientras que Kenichi Ohmae (citado por Rojo, 1998) va aún más lejos 
sugiriendo que sus propias actividades como administrador son cada vez más obsoletas: "muchos de los valores esenciales que servían de fundamento a un orden mundial de Estados nación, por ejemplo, la democracia liberal tal como se practica en Occidente e incluso la idea misma de soberanía política, están mostrando una necesidad seria de redefinición, o quizá de reemplazo".

En este contexto, no resulta demasiado difícil entender cómo es que han progresado las oportunidades no sólo para el surgimiento, sino sobre todo para la acción independiente de nuevos actores sociales en materia de contacto con sus contrapartes en el exterior. El debilitamiento estructural del estado, promovido por la política exterior norteamericana como mecanismo de preservación de su poder hegemónico ha facilitado la tarea simplemente atribuyendo el florecimiento de estas condiciones al desarrollo "natural" del proceso globalizador.

\section{La paradiplomacia en el mundo actual}

Uno de los aspectos que más sobresale al analizar la dinámica del sistema internacional de principios del tercer milenio es la notable interconectividad que se ha logrado entre los rincones más distantes del sistema en tan poco tiempo. La dinámica de los intercambios entre todos los actores del sistema hoy en día es tan intensa, que, por primera vez, la vieja idea de McLuhan sobre una aldea global tiene un sentido práctico y un referente empírico concreto para la mayor parte de la población mundial.

Los optimistas buscan, desde luego, maximizar las ventanas de oportunidad que la creciente interconectividad del mundo ofrece a todos los actores del sistema: mayor comercio, mayores oportunidades de inversión, de intercambio cultural, etc. Los pesimistas no se cansan de señalar los riesgos: mayor contaminación, mayores niveles de delincuencia, mayores desequilibrios para el ecosistema planetario, etc. La lista puede ser considerablemente larga de cada lado; hay quienes creen que este es el único camino hacia un auténtico desarrollo universal, y algunos otros están convencidos de que la catástrofe que el proceso propicia es inminente. 
Lo que es un hecho es que esta dinámica acelerada de interconectividad global ha abierto importantes oportunidades laborales para los internacionalistas. Con un número creciente de actores interesados en promover sus intereses en el exterior, en atraer inversión a sus regiones o turismo a sus ciudades, en fin de hacerse presente para la otredad y abrirse al contacto con ella, la necesidad de profesionales capacitados en esta área es cada vez más grande. Los expertos en multiculturalidad, negocios con el extranjero, solución de conflictos, seguridad, etc. están siendo cada vez más solicitados. Todo este es, de alguna manera, campo natural de desarrollo de la paradiplomacia.

No obstante, trabajar al margen de los conductos oficiales del estado conlleva también riesgos inminentes que hay que saber reconocer de manera oportuna para evitar el fomento a las actividades al margen de la ley o un debilitamiento excesivo de las autoridades estatales tal que deje a los individuos sin la protección mínima que el aparato estatal debe ofrecer.

Como hemos señalado, la paradiplomacia bien puede ser un mecanismo de facilitación de la gobernanza mundial, siempre y cuando permita la operatividad de las instituciones que deben ofrecerla y administrarla. Aquí permanece un reto importante para el sistema internacional de nuestros días: el logro del equilibrio entre la actividad de los diversos actores internacionales que están proliferando en el sistema y desempeñándose por cuenta propia y la actividad reguladora de alguna instancia capaz de mantener la armonía entre todos ellos, sin ser vista como una imposición hegemónica. No es un reto fácil de resolver.

Desde luego, es importante mantener vigentes los espacios de actuación para actores internacionales subestatales, supraestatales, transnacionales o no estatales en la promoción de sus propios intereses. Eso es precisamente lo que las actividades paradiplomáticas buscan hacer. Pero es igualmente importante institucionalizar el proceso y permitir el desempeño de instancias reguladores que eviten el caos o el abuso por parte de los más poderosos. 


\section{Conclusiones}

Como cualquier otro fenómeno internacional, la paradiplomacia es producto de una regularidad sociológica que deviene de la existencia de grupos humanos políticamente autónomos y culturalmente diferenciados que entablan relaciones entre sí en un determinado contexto geográfico, dando paso a la construcción de sistemas históricos internacionales. En este sentido, no es difícil encontrar ejemplos de actividad paradiplomática en otras épocas.

Sin embargo, al igual que otros fenómenos sociales, adquiere su especificidad histórica en un escenario geo-histórico concreto. En este sentido, la paradiplomacia posee rasgos característicos del mundo globalizado de principios del tercer milenio de la era cristiana, que están relacionados, efectivamente, con el debilitamiento de las estructuras tradicionales del estado nacional, tal como fue concebido y promovido por la política exterior norteamericana a finales de la segunda guerra mundial.

Este debilitamiento es producto de los esfuerzos hegemónicos de esa política exterior norteamericana que busca la imposición de condiciones sistémicas afines a sus intereses y sus valores, dando al mundo globalizado un perfil americano predominante .

Además, el desarrollo de la paradiplomacia ha sido posible gracias a la conjunción de diversos factores, entre los que destacan: la proliferación de nuevos actores internacionales, la imposición del modelo neoliberal como esquema de actualización del capitalismo contemporáneo, la creciente participación del sector privado en diversos sectores de la economía, la revolución en los medios de comunicación de la era digital, etc.

Como fenómeno social, conlleva riesgos inminentes sobre los que es preciso mantener ojo avizor, por ejemplo, puede fácilmente exacerbar los problemas de distribución equitativa de la riqueza, permitiendo su monopolización en cada vez menos manos, abrir la puerta a mayores márgenes de actividad delincuencial habida cuenta del debilitamiento 
de las estructuras tradicionales del Estado, incrementar la amenaza de tendencias consumistas irracionales que aceleren el desequilibrio ambiental del planeta, favorecer la imposición de modelos culturales hegemónicos sobre el resto del mundo, etc. Pero también implica importantes oportunidades de democratización de la vida social, replanteamiento de los modelos tradicionales de desarrollo, y gobernanza mundial.

El rumbo que pueda tomar el proceso dependerá en gran medida de la capacidad que tengamos para reconocerlo, tanto en su dimensión de amenaza como en la de oportunidad para la construcción de una auténtica comunidad internacional. La moneda está en el aire y con ella, en gran medida el destino de la humanidad.

\section{Referencias}

Anderson, B. (2006). Comunidades imaginadas: reflexiones sobre el origen y la difusuón del nacionalismo. México: FCE.

Aron, R. (1967). ¿Qué es una teoría de las relaciones internacionales? En Revista de Humanidades 4.

Berreby, D. (2006). Us vs. Them: understanding your tribal mind. Londres: Hutchinson.

Bodin, J. (1576). Los seis libros de la república. Recuperado de www.juridica. unam.mx

Drucker, F. P. (1990). Las nuevas realidades. México: Sudamericana.

Friedman, T. (1999). The Lexus and the olive tree: understanding globalization. Nueva York: Straus y Giroux.

Hernández-Vela, Salgado, E. (2002). Diccionario de política internacional. México: Porrúa.

Kelsen, H. (1934). Teoría General del Estado. Barcelona: Labor.

López Vega, A. (2014). 1914: el año que cambió la historia. Madrid: Taurus.

Mazower, M. (2012). Governing the world: the bistory of an idea. Londres: Penguin.

Rifkin, J. (2010). The Empathic Civilization: The Race to Global Consciousness In a World In Crisis. Cambridge: Polity Press.

Rojo, G., et al. (1998). Globalización culturaly postmodernidad. Santiago de Chile: Fondo de Cultura Económica. 
Sarquís, D. (2005). Relaciones internacionales: una perspectiva sistémica. México: M.A. Porrúa.

Sarquis, D. (2012). La dimensión histórica en el estudio de las relaciones internacionales: elproceso de reconstrucción de sistemas históricos internacionales. México: Grial. Sarquis, D. (2013). Fundamentos teóricos para la reflexión en torno a la paradiplomacia. En Zeraoui, Z. (coord.). Teoría y práctica de la paradiplomacia. Puebla: Montiel \& Soriano.

Sarquis, D. (2014). ¿Deben ser consideradas las relaciones internacionales como una disciplina autónoma? En J. Schiavon, et al, Teorías de relaciones internacionales en el siglo XXI: interpretaciones críticas desde México. México: UABC, BUAP, COLSAN, UANL y UPAEP.

Teschke, B. (2003). The myth of 1648: Class, geopolitics and the making of modern international relation. Londres: Verso.

Velázquez Flores, R. (2007). Factores, bases y fundamentos de la política exterior de México. México: Plaza y Valdez y Universidad del Mar.

Wallerstein, I. (1995). Abrir las ciencias sociales. México: Siglo XXI.

Wallerstein, I. (1997). Análisis de sistemas-mundo: una introducción. México: Siglo XXI.

Yongjin, Z., (2015). Historia, filosofía e innovación teórica en las relaciones internacionales desde la perspectiva china: un breve comentario. Perspectiva Global 4.

Zeraoui, Z., (2013). Teoría y práctica de la paradiplomacia. Puebla: Montiel \& Soriano. 